\title{
Biogeochemical conditions determine virulence of black band disease in corals
}

\author{
Martin S Glas ${ }^{1}$, Yui Sato ${ }^{2,3}$, Karin E Ulstrup ${ }^{4}$ and David G Bourne ${ }^{2}$ \\ ${ }^{1}$ Max Planck Institute for Marine Microbiology, Microsensor Group, Bremen, Bremen, Germany; ${ }^{2}$ Centre of \\ Marine Microbiology and Genetics, Australian Institute of Marine Science, PMB 3, Townsville, Queensland, \\ Australia; ${ }^{3}$ ARC Centre of Excellence for Coral Reef Studies and School of Marine and Tropical Biology, \\ James Cook University, and AIMS@JCU, Townsville, Queensland, Australia and ${ }^{4} D H I$ Water \& Environment, \\ West Perth, Western Australia, Australia
}

\begin{abstract}
The microenvironmental dynamics of the microbial mat of black band disease (BBD) and its less virulent precursor, cyanobacterial patch (CP), were extensively profiled using microsensors under different light intensities with respect to $\mathrm{O}_{2}, \mathrm{pH}$ and $\mathrm{H}_{2} \mathrm{~S}$. BBD mats exhibited vertical stratification into an upper phototrophic and lower anoxic and sulphidic zone. At the progression front of BBD lesions, high sulphide levels up to $4977 \mu \mathrm{M}$ were measured in darkness along with lower than ambient levels of $\mathrm{pH}(7.43 \pm 0.20)$. At the base of the coral-BBD microbial mat, conditions were hypoxic or anoxic depending on light intensity exposure. In contrast, CP mats did not exhibit strong microchemical stratification with mostly supersaturated oxygen conditions throughout the mats at all light intensities and with levels of pH generally higher than in BBD. Two of three replicate CP mats were devoid of sulphide, while the third replicate showed only low levels of sulphide (up to $42 \mu \mathrm{M}$ ) present in darkness and at intermediate light levels. The level of oxygenation and sulphide correlated well with lesion migration rates, that is virulence of the mats, which were greater in BBD than in CP. The results suggest that biogeochemical microgradients of BBD shaped by the complex microbial community, rather than a defined pathogen, are the major trigger for high virulence and the associated derived coral mortality of this disease.
\end{abstract}

The ISME Journal (2012) 6, 1526-1534; doi:10.1038/ismej.2012.2; published online 9 February 2012

Subject Category: microbe-microbe and microbe-host interactions

Keywords: BBD; CP; pathogen; microsensor; anoxia; sulphide

\section{Introduction}

Black band disease (BBD) is a highly virulent coral disease that affects scleractinian corals, the major reef builders in tropical reef ecosystems around the world (Sutherland et al., 2004). It manifests as a complex microbial mat that migrates over coral tissue, resulting in lysis and necrosis of the underlying coral tissue, leaving bare coral skeleton behind (Richardson, 2004). Despite being first identified in 1973 (Antonius, 1973), the aetiology and underlying mechanisms of pathogenesis and pathogenicity of $\mathrm{BBD}$ remain unresolved, as no primary pathogen has been identified and various causes for the disease's high virulence are still debated.

BBD comprises a complex microbial community including phototrophic cyanobacteria, sulphatereducing bacteria (SRB), sulphide-oxidizing bacteria

Correspondence: DG Bourne, Centre of Marine Microbiology and Genetics, Australian Institute of Marine Science, PMB 3, Townsville MC, Townsville, Queensland 4810, Australia.

E-mail: d.bourne@aims.gov.au

Received 10 October 2011; revised 2 January 2012; accepted 2 January 2012; published online 9 February 2012 and other heterotrophic bacteria (Cooney et al., 2002; Frias-Lopez et al., 2004; Barneah et al., 2007; Voss et al., 2007; Sekar et al., 2008; Sato et al., 2010). The BBD lesion therefore closely resembles that of other complex microbial mats, as suggested by Carlton and Richardson (1995), including hypersaline mats, which are vertically stratified into an upper phototrophic zone and a lower anoxic-sulphidic zone (Jonkers et al., 2003; Dupraz et al., 2004, 2009; Ludwig et al., 2005; Dillon et al., 2009). The stratification in hypersaline mats is mainly driven by gliding filamentous members (cyanobacteria, Beggiatoa sp.) that are highly motile and exhibit active diurnal migration (Fourcans et al., 2006; Hinck et al., 2007; Dillon et al., 2009). The vertical orientation of functional groups within hypersaline mats results in the development of pronounced biogeochemical microgradients (e.g., $\mathrm{O}_{2}$, light, $\mathrm{pH}$, sulphate and sulphide), reciprocally influenced by and influencing their environment. Such conditions enable tight spatial coupling of matter cycling, further driving development of functionally differentiated, stratified communities. Similar modulations of biogeochemical microgradients in BBD lesions are likely (Carlton and Richardson, 1995) 
and may be an important trigger for high virulence at the base of the mat (coral-microbial mat interphase), where healthy tissue, necrosing tissue and the microbial consortium interact.

Biogeochemical conditions at the base of the BBD mat are typically hypoxic or anoxic with high concentrations of sulphide lethal to the underlying coral tissue. Such detrimental biogeochemical conditions established within and at the base of the mat have previously been suggested as virulence factors for BBD (Richardson et al., 1997). Yet, sulphide estimations within the microbial mat of BBD have focused on microsensor measurements of the $\mathrm{S}^{2-}$ fraction only, without taking $\mathrm{pH}$ variations within the mat into account (Carlton and Richardson, 1995). Importantly, the dissociation of the three sulphide species in seawater $\left(\mathrm{H}_{2} \mathrm{~S}\right.$, HS ${ }^{-}$and $\left.\mathrm{S}^{2-}\right)$ integrally depends on $\mathrm{pH}$ (Millero and Hershey, 1989) and the attained results therefore do not quantify total sulphide. Accurate measurements of the spatiotemporal dynamics of total sulphide is the key to understanding the onset and aetiology of BBD, as toxicity estimates for the coral tissue depend on the levels of total sulphide present (Vismann, 1991; Bagarinao, 1992; Richardson et al., 1997).

An outbreak of BBD and an earlier less-virulent stage of the disease, termed 'cyanobacterial patch' (CP), has been documented on Montipora coral species around Orpheus Island, within the Great Barrier Reef Marine Park (Sato et al., 2009, 2010). Transitions of CP-like lesions into developed BBD have also been observed on Indonesian reefs (B Willis, personal communication). In the field, BBD lesions develop from CP approximately 62 days following the onset of the CP lesion (Sato et al., 2010). Shifts in the microbial community structure as CP transitioned into BBD (Glas et al., 2010; Sato et al., 2010) included increases in sulphate-reducing bacterial (SRB) populations, namely Desulfovibrio sp. (Bourne et al., 2011). This disease outbreak around Orpheus Island also provided the opportunity to examine biogeochemical microgradients within the microbial mats, and the role microenvironmental conditions play in the virulence of BBD as well as the onset of BBD from CP.

To investigate if the high virulence of $\mathrm{BBD}$ is driven by the dynamic microenvironmental conditions within and at the base of the mat, we extensively profiled coral fragments infected with BBD and CP under controlled laboratory conditions with $\mathrm{O}_{2}$, pH and $\mathrm{H}_{2} \mathrm{~S}$ (measuring the dissolved $\mathrm{H}_{2} \mathrm{~S}$ fraction) microsensors. The microsensor measurements were complemented with molecular quantification of sulphate reducers within the mat. The main aim of this study was therefore to further our understanding of virulence of $\mathrm{CP}$ and $\mathrm{BBD}$ by determining the spatio-temporal dynamics of $\mathrm{pH}$, total sulphide and oxygen within and at the base of CP and BBD microbial mats and relate these results to the typical fast directional migration (virulence) of the corresponding lesions.

\section{Materials and methods}

\section{Sampling and culturing}

Samples of the scleractinian coral Montipora hispida infected with either CP or BBD $(n=3$ colonies each, labelled as BBD no. 1-3 and CP no. 1-3) were collected in March 2010, using a hammer and chisel along the northeast coast of Pelorus Island $\left(18^{\circ} 32^{\prime} \mathrm{S}\right.$, $146^{\circ} 30^{\prime} \mathrm{E}$; central region of the Great Barrier Reef Marine Park, east coast of Australia), at depths of 3.5-4.5 $\mathrm{m}$ (for a detailed description of the study site, see Sato et al., 2009). Coral fragments infected with lesions of CP or BBD were carefully placed in separate 70-1 cooling boxes containing ambient seawater, and immediately transported to the Australian Institute of Marine Science in Townsville. Samples were maintained in an indoor aquarium facility at $26^{\circ} \mathrm{C}$ to avoid thermally induced transition of $\mathrm{CP}$ into BBD due to prevalent high summer temperatures (Glas et al., 2010). The facility provided a flow of freshly filtered seawater $\left(3 \mathrm{~cm} \mathrm{~s}^{-1}\right)$ and light intensities of $\sim 100 \mu \mathrm{mol}$ photons $\mathrm{m}^{-2} \mathrm{~s}^{-1}(12 \mathrm{~h}: 12 \mathrm{~h}$ diurnal cycling).

\section{Experimental measurement setup}

All amperiometric and potentiometric microsensor measurements were conducted in a self-constructed Faraday cage to minimize electrical disturbance. A detailed description of the measurement setup can be found in Polerecky et al. (2007). Diseased corals fragments were placed in a flow chamber on top of inert sand connected to a circulation system of filtered, aerated natural seawater $(1 \mu \mathrm{m}$ mesh size, 50 l). Seawater conditions were monitored throughout the experiment and kept constant at $26^{\circ} \mathrm{C}$, salinity 35 , oxygen saturation of $207.8 \pm 0.4 \mu \mathrm{M}$ (mean \pm s.e.), $\mathrm{pH}$ (total scale) $8.062 \pm 0.005$ (mean \pm s.e.) and a laminar flow of $1 \mathrm{~cm} \mathrm{~s}^{-1}$. Illumination was provided and regulated directly from above via a fiber-optic guide from a halogen-light source (Schott KL2500, Mainz, Germany). Light intensities were monitored with a quantum irradiance meter (LI-250A, LI-COR, Lincoln, NE, USA), combined with a light sensor for photosynthetic active radiation (PAR).

\section{Microelectrodes}

Clark-type $\mathrm{O} 2$ microsensors with a guard cathode (tip diameter $\sim 40 \mu \mathrm{m},<1 \mathrm{~s}$ response time $\left(t_{90}\right)$, detection limit $0.05 \mu \mathrm{M}$ ) were constructed and calibrated as previously described (Revsbech and Jørgensen, 1986). Fast responding $\mathrm{H}_{2} \mathrm{~S}$ sensors (tip diameter $\sim 50 \mu \mathrm{m},<1 \mathrm{~s}$ response time $\left(t_{90}\right)$, detection limit $0.1 \mu \mathrm{M}$ at $\mathrm{pH}<9$ ) with an internal reference were prepared and used as previously described (Jeroschewski et al., 1996; Kühl et al., 1998). Five-point $\mathrm{H}_{2} \mathrm{~S}$ calibrations were performed in anoxic, filtered, acidified natural seawater $(\mathrm{pH}<4)$ and exhibiting linear responses up to $1000 \mu \mathrm{M}\left(R^{2}>0.99\right)$. $\mathrm{pH}$ measurements were performed on the total scale, by 


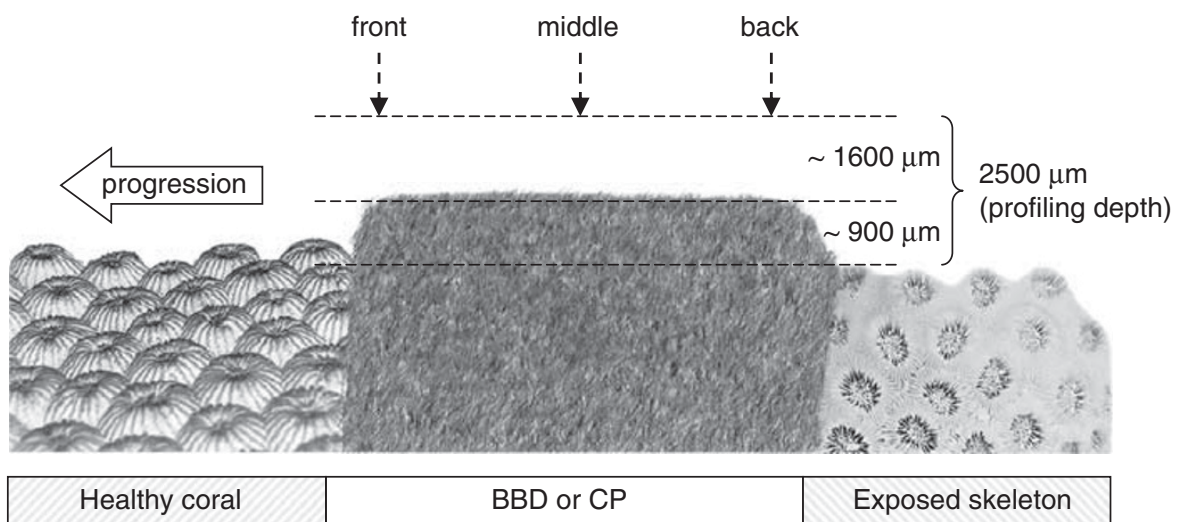

Figure 1 Schematic drawing of profile series conducted for individual disease lesions (CP and BBD). Thickness of microbial mat and profiling depth are exaggerated for clarity.

using liquid ion exchange (LIX) membrane microelectrodes (tip diameter $20 \mu \mathrm{m},<2 \mathrm{~s}$ response time $\left(t_{90}\right)$, detection limit 0.005$)$ as described by de Beer (2000) and a commercial $\mathrm{pH}$ meter ( $\mathrm{pH} 1100$, Oakton, Vernon Hills, IL, USA).

\section{Experimental procedure}

Measurement series of $\mathrm{pH}$ and $\mathrm{H}_{2} \mathrm{~S}$ profiles were conducted in three locations across both BBD and CP lesions (lesion's front, middle and back, Figure 1) $(n=3)$ and repeated at three different irradiances $(0$, 40 and $250 \mu \mathrm{mol}$ photons $\mathrm{m}^{-2} \mathrm{~s}^{-1}$ ) to simulate in situ underwater light levels for night-time, transient light and day-time light regimes. Total sulphide $\left(\mathrm{S}_{\text {tot }}=\left[\mathrm{H}_{2} \mathrm{~S}\right]+\left[\mathrm{HS}^{-}\right]+\left[\mathrm{S}^{2-}\right]\right)$ profiles were calculated from aligned values of $\mathrm{pH}$ and $\mathrm{H}_{2} \mathrm{~S}$ profiles as described by Jeroschewski et al. (1996) (equations (6) and (7)). The dissociation constant $K_{1}$, expressed as $\mathrm{pK}_{1}$, was corrected for temperature and salinity according to Millero et al. (1988) (equation (4)) and Millero and Hershey (1989, equation (22)).

$\mathrm{O}_{2}$ measurements were carried out at the lesion's front only, following preliminary measurements showing no horizontal gradient of $\mathrm{O}_{2}$ across BBD and CP mats. Four different irradiances (0, 60, 125, $485 \mu \mathrm{mol}$ photons $\mathrm{m}^{-2} \mathrm{~s}^{-1}$, Table 1) were selected to estimate peak $\mathrm{O}_{2}$ evolution at maximal in situ light levels (Sato et al., 2009).

To determine the $t_{90}$ value of steady-state signals of the system $\mathrm{O}_{2}, \mathrm{pH}$ and $\mathrm{H}_{2} \mathrm{~S}$ probes were positioned at the mat surface as well as at $400 \mu \mathrm{m}$ and at $900 \mu \mathrm{m}$ depth within the mat for $\sim 40 \mathrm{~min} . \mathrm{O}_{2}$ and $\mathrm{H}_{2} \mathrm{~S}$ signals (pA) reached $>90 \%$ of steady-state signals within 3-7 min, $\mathrm{pH}$ values $(\mathrm{mV})$ took 9-13 min. To ensure steady state, light levels were applied $>10 \mathrm{~min}$ prior to measurements for $\mathrm{O}_{2}$ and $\mathrm{H}_{2} \mathrm{~S}$, and $>20$ min for $\mathrm{pH}$ measurements. Microsensor tips were positioned in contact with $\mathrm{BBD}$ or $\mathrm{CP}$ mat surfaces using a stereo microscope and a 3D-manual micromanipulator (MM33, Maerzhaeuser, Germany). Profiles were conducted perpendicular to the mat surface from $\sim 1600 \mu \mathrm{m}$ above and $\sim 900 \mu \mathrm{m}$ into the mats covering the diffusive boundary layer (Figure 1).
Mat-migration speed was determined at the end of the experiment (after $48 \mathrm{~h}$ ) with a digital caliper by measuring band extensions along the migration direction in a 1-cm big strip enclosing the profiling transect $(n=5)$. Developmental stages of lesions were visually classified at the start and end of the experiment on a scale from 1 to 10 (CP 1-5, BBD 6-10) by determining lesion colour, shading, surface structure and density via the stereomicroscope. Immediately after the completion of microsensor measurements, BBD and CP lesions were sampled from coral fragments with sterile forceps and subsequently weighed and preserved for molecular and pigment analyses.

\section{Quantification of sulphate reducers}

A quantitative real-time PCR (qPCR) assay targeting the dissimilatory (bi)sulphite reductase $(d s r A)$ gene of sulphate-reducing bacteria (SRB) and a qPCR assay targeting the 16S rRNA gene, as detailed in Bourne et al. (2011), provided an estimate of SRB populations relative to total bacteria within the sampled mats. The $d s r A$ gene was targeted with primers DSR1-F + and DSR-R, adapted from Kondo et al. (2008) and Leloup et al. (2007), though modified through the use of the TaqMan chemistry and an additional internal probe (DSRtaq (HEX)-5'-CCGATAACRCYGCCGCCGTAACC GA-3'-(TAMARA)), allowing increased specificity and discrimination in quantification of $d s r A$ genes within samples (Bourne et al., 2011). Quantification of the bacterial abundance through targeting of the $16 \mathrm{~S}$ rRNA gene was adapted from Nadkarni et al. (2002) and applied the universal primers 331-F ( $5^{\prime}$-TCCTACGGGAGGCAGCAGT-3'), 797-R (5'-GGAC TACCAGGGTATCTAATCCTGTT- $3^{\prime}$ ), and the probe BacTaq ((6-FAM)-5'-CGTATTACCGCGGCTGCTGG CAC-3'-(TAMARA)), targeting almost all bacterial phyla.

\section{Chlorophyll a concentrations}

Chlorophyll $a$ (Chl $a$ ) within the mat samples of CP and BBD was extracted by sonication in $1 \mathrm{ml}$ buffered 
Table $1 \mathrm{O}_{2}$ concentration (mean \pm s.e., $\mu \mathrm{M}$ ) measured at the coral-microbial mat interphase (at $0 \mu \mathrm{m}$, see Figure 3) of CP and BBD in darkness and at three irradiances

\begin{tabular}{lcc}
\hline $\begin{array}{l}\text { Light } \\
\left(\mu \mathrm{mol} \text { photons } \mathrm{m}^{-2} \mathrm{~s}^{-1}\right)\end{array}$ & $C P(\mathrm{n}=3)$ & $B B D(\mathrm{n}=3)$ \\
\hline 0 & $23 \pm 17$ & $2 \pm 2$ \\
60 & $247 \pm 28$ & $19 \pm 19$ \\
125 & $468 \pm 41$ & $80 \pm 73$ \\
485 & $1133 \pm 19$ & $467 \pm 219$ \\
\hline
\end{tabular}

Abbreviations: BBD, black band disease; CP, cyanobacterial patch.

methanol (98\% methanol, $2 \%$ of $0.5 \mathrm{M}$ tetrabutyl ammonium acetate at $\mathrm{pH}$ 6.5) on ice. Samples were centrifuged and the supernatant decanted with a pipette before repeating the extraction with $0.8 \mathrm{ml}$ of buffered methanol and combining both extracts. Chl $a$ was determined spectrophotometrically $(1 \mathrm{~cm}$ path length) using the equations detailed in Porra (2002).

\section{Data analyses}

Linear regressions between daily mean migration speeds and biogeochemical parameters from the front and base of the microbial mats $\left(\mathrm{S}_{\text {tot }}, \mathrm{O}_{2}\right.$ and $\left.\mathrm{pH}\right)$, relative abundance of SRB, developmental stages and Chl $a$ contents were assessed using Pearson productmoment correlation coefficient $(R)$ and a general linear-regression model. Tested values of $S_{\text {tot }}, \mathrm{O}_{2}$ and $\mathrm{pH}$ used in the analyses represent daily average values calculated as means from steady-state light (125 and $250 \mu \mathrm{mol}$ photons $\mathrm{m}^{-2} \mathrm{~s}^{-1}$ ) and dark values from the front and base of the microbial mats. Regression analyses were performed with the statistical analyses software Origin 7.0 (OriginLab Corporation, Northampton, MA, USA).

\section{Results}

Biochemical profiles of $C P$ and BBD lesions

$\mathrm{CP}$ mats were mostly devoid of $\mathrm{H}_{2} \mathrm{~S}$ and $\mathrm{S}_{\text {tot }}$ at all light levels, with the exception of one sample (CP no. 1) where $\mathrm{H}_{2} \mathrm{~S}(\sim 1 \mu \mathrm{M})$ and $S_{\text {tot }}(<42 \mu \mathrm{M})$ were observed in dark and at intermediate light levels (Supplementary Figure S1 and Figure 2). In darkness, the base at the progression front of all CP mats was hypoxic $(23 \pm 17 \mu \mathrm{M}$, Table 1$)$, with lower than ambient $\mathrm{pH}(7.73 \pm 0.25$, Table 2$)$ and with profiles of decreasing $\mathrm{O}_{2}$ and $\mathrm{pH}$ towards the base of the mat as exemplified in Figure 3. The base at the progression front of the CP mats was supersaturated with respect to $\mathrm{O}_{2}$ levels $\geqslant 60 \mu \mathrm{mol}$ photons $\mathrm{m}^{-2} \mathrm{~s}^{-1}$ (Table 1). At intermediate light levels $(40 \mu \mathrm{mol}$ photons $\left.\mathrm{m}^{-2} \mathrm{~s}^{-1}\right), \mathrm{pH}$ at the base of the progression front was still lower than ambient $(7.83 \pm 0.26)$, although it was greater $(8.61 \pm 0.19)$ than ambient at $250 \mu \mathrm{mol}$ photons $\mathrm{m}^{-2} \mathrm{~s}^{-1}$ (Table 2). At $125 \mu \mathrm{mol}$ photons $\mu \mathrm{m}^{-2} \mathrm{~s}^{-1}$, the front of the CP mats were $\mathrm{O}_{2}$ supersaturated throughout as exemplified in
Figure 3. At the maximum irradiance level of $485 \mu \mathrm{mol}$ photons $\mathrm{m}^{-2} \mathrm{~s}^{-1}, \mathrm{O}_{2}$ concentrations reached $1133 \pm 19 \mu \mathrm{M}$ at the front and base of the CP mats (Table 1).

The base of BBD microbial mats was anoxic in darkness (Table 1), with lower than ambient $\mathrm{pH}$ (Table 2) and high concentrations of $\mathrm{H}_{2} \mathrm{~S}$ at the progression front (Supplementary Figure S1). Clear vertical gradients of decreasing $\mathrm{O}_{2}$ and $\mathrm{pH}$ were observed in darkness towards the BBD mat surface and of increasing $\mathrm{H}_{2} \mathrm{~S}$ towards the base (Figure 3). Also, if present, $\mathrm{H}_{2} \mathrm{~S}$ showed a horizontal gradient with highest $\mathrm{H}_{2} \mathrm{~S}$ levels at the progression front of the lesion, and lowest at the back at all light levels (Supplementary Figure $\mathrm{S} 1$ ). $\mathrm{O}_{2}$ supersaturation was observed at $125 \mu \mathrm{mol}$ photons $\mathrm{m}^{-2} \mathrm{~s}^{-1}$ at the BBD mat surface as indicated in Figure 3 and only at $485 \mu \mathrm{mol}$ photons $\mathrm{m}^{-2} \mathrm{~s}^{-1}$ at the base (Table 1).

Calculations of total sulphide in BBD lesions consistently revealed strong vertical and horizontal spatial gradients from front to back of the lesions at all light levels, with large inter-colony variations in maximum $\mathrm{H}_{2} \mathrm{~S}$ and consequently $S_{\text {tot }}$ (Supplementary Figure S1 and Figure 2). In all samples (with the exception of BBD no. 2 at intermediate light levels) sulphide accumulation was highest at the base of the progression front of BBD mats, where coral tissue was freshly covered and undergoing necrosis (Figure 2). Sulphide concentrations varied with light intensity and gradients decreased horizontally in extent with increasing light intensities (Figure 2). $S_{\text {tot }}$ was detectable $1000 \mu \mathrm{m}$ above the microbial mat surface in BBD no. 1 in darkness and still accumulated up to $450 \mu \mathrm{M}$ at the base of the progression front in daylight (Figure 2).

Overall, in darkness, oxygen was depleted throughout BDD mats, while low concentrations of oxygen were still present towards the base of the CP mats (Table 1 and Figure 3). Levels of $\mathrm{pH}$ at the base of the mats, though highly variable, were generally lower in BBD than in CP (Table 2). Compared with CP, BBD displayed a more defined stratification into a lower (coral tissue-microbial mat interphase) anoxic-sulphidic zone and an upper phototrophic zone.

\section{Virulence and microenvironmental correlates}

BBD showed greater mean migration speeds (1.41-8. $63 \mathrm{~mm} \mathrm{day}^{-1}$ ) than CP (0.01-1.18 mm day $\left.{ }^{-1}\right)$, indicating an increased virulence of BBD compared with CP (Table 3). Mean migration rates were significantly correlated with developmental stages of the lesion $(P=0.042)$, presence of sulphide $(P=0.008)$ and anoxic conditions $(P=0.024)$ at the base of the progression front (Table 3). Relative quantification of the $d s r A$ gene showed that the contribution of SRB to the total bacterial population increased in BBD relative to CP. However, the presence of sulphide followed trends in oxygenation and therefore the biogeochemical condition of the mats, rather 


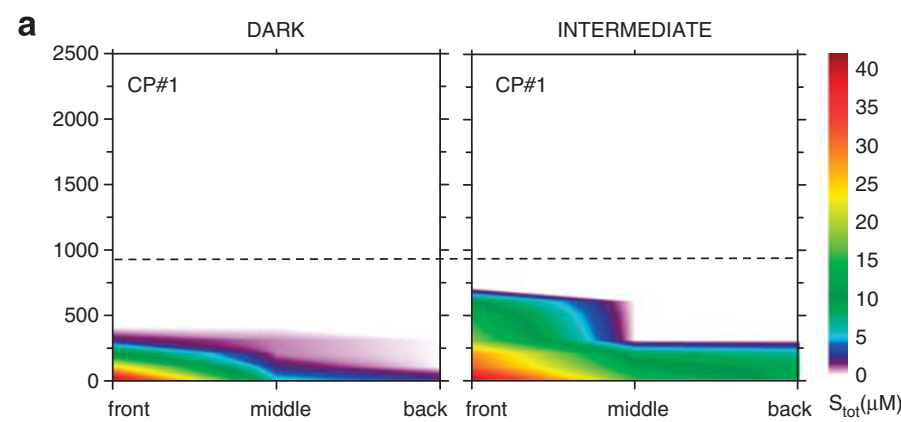

b

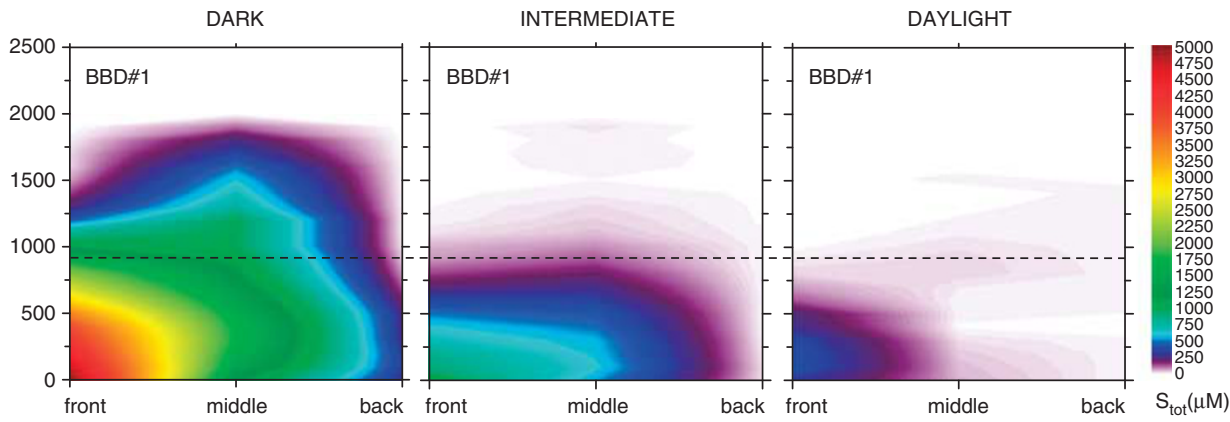

C
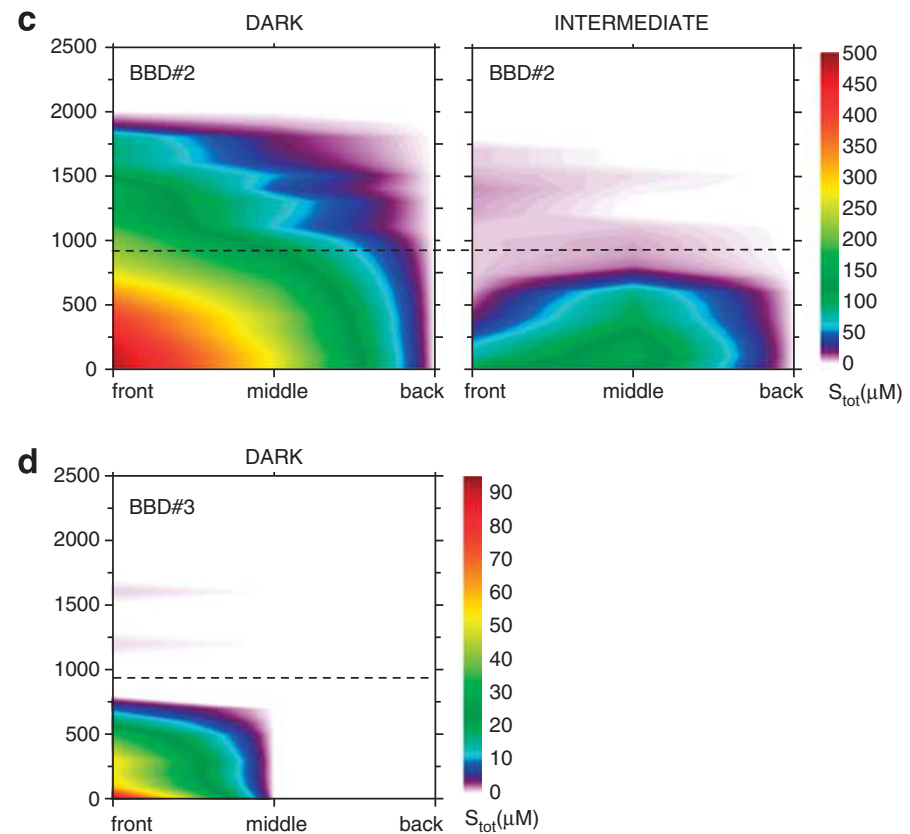

Figure 2 Spatial distribution of total sulphide $\left(S_{\text {tot }}\right)$ concentrations for (a) CP no. 1, (b) BBD no. 1, (c) BBD no. 2 and (d) BBD no. 3 at three different light intensities (darkness $=0$, intermediate $=40$, daylight $=250 \mu \mathrm{mol}$ photons $\mathrm{m}^{-2} \mathrm{~s}^{-1}$ ). Dotted lines indicate the surface of the microbial mats. Scale bars in (a-d) are different to allow the representation of $S_{\text {tot }}$ in all contour plots. Daylight contour plots for CP no. 1, BBD no. 2, as well as daylight and intermediate contour plots for BBD no. 3 were omitted as they did not contain any sulphide. All contour plots for CP no. 2 and CP no. 3 were also omitted as they did not contain any sulphide.

than the abundance of $d s r A$ genes (Table 3). The linear regression analyses showed that mean migration rates were explained better by $\mathrm{O}_{2}$ and $\mathrm{S}_{\text {tot }}$ concentrations at the base of the progression front of BBD and CP than by $\mathrm{pH}$ and SRB abundance (Table 3). Chl $a$ contents also correlated significantly $(P=0.016)$ with migration speeds (Table 3$)$, indicating the presence of high phototrophic biomass within more virulent lesions.

\section{Discussion}

Biogeochemistry of BBD and CP microbial mats The tight coupling of $\mathrm{pH}, \mathrm{O}_{2}$ and total sulphide was characteristic of all disease lesion replicates. It resulted in the development of clearly defined microgradients within the BBD microbial mat, causing a clear stratification into an upper phototrophic (oxygenic) and lower anoxic-sulphidic zone 
Table $2 \mathrm{pH}$ (mean \pm s.e.) measured at the coral-microbial mat interphase (at $0 \mu \mathrm{m}$, see Figure 3 ) of CP and BBD in darkness and at two irradiances

\begin{tabular}{|c|c|c|c|c|c|c|}
\hline \multirow{2}{*}{$\begin{array}{l}\text { Light }(\mu \mathrm{mol} \\
\left.\text { photons } \mathrm{m}^{-2} \mathrm{~s}^{-1}\right)\end{array}$} & \multicolumn{3}{|c|}{$C P$} & \multicolumn{3}{|c|}{$B B D$} \\
\hline & $\begin{array}{l}\text { Front } \\
(\mathrm{n}=3)\end{array}$ & $\begin{array}{l}\text { Middle } \\
(\mathrm{n}=3)\end{array}$ & $\begin{array}{l}\text { Back } \\
(\mathrm{n}=3)\end{array}$ & $\begin{array}{l}\text { Front } \\
(\mathrm{n}=3)\end{array}$ & $\begin{array}{l}\text { Middle } \\
(\mathrm{n}=3)\end{array}$ & $\begin{array}{l}\text { Back } \\
(\mathrm{n}=3)\end{array}$ \\
\hline 0 & $7.73 \pm 0.25$ & $7.53 \pm 0.14$ & $7.75 \pm 0.07$ & $7.43 \pm 0.20$ & $7.33 \pm 0.11$ & $7.49 \pm 0.03$ \\
\hline 40 & $7.83 \pm 0.26$ & $7.74 \pm 0.22$ & $7.39 \pm 0.23$ & $7.37 \pm 0.01$ & $7.62 \pm 0.11$ & $7.49 \pm 0.19$ \\
\hline 250 & $8.61 \pm 0.19$ & $8.58 \pm 0.22$ & $8.54 \pm 0.07$ & $7.58 \pm 0.15$ & $8.13 \pm 0.27$ & $7.83 \pm 0.24$ \\
\hline
\end{tabular}

Abbreviations: BBD, black band disease; CP, cyanobacterial patch.
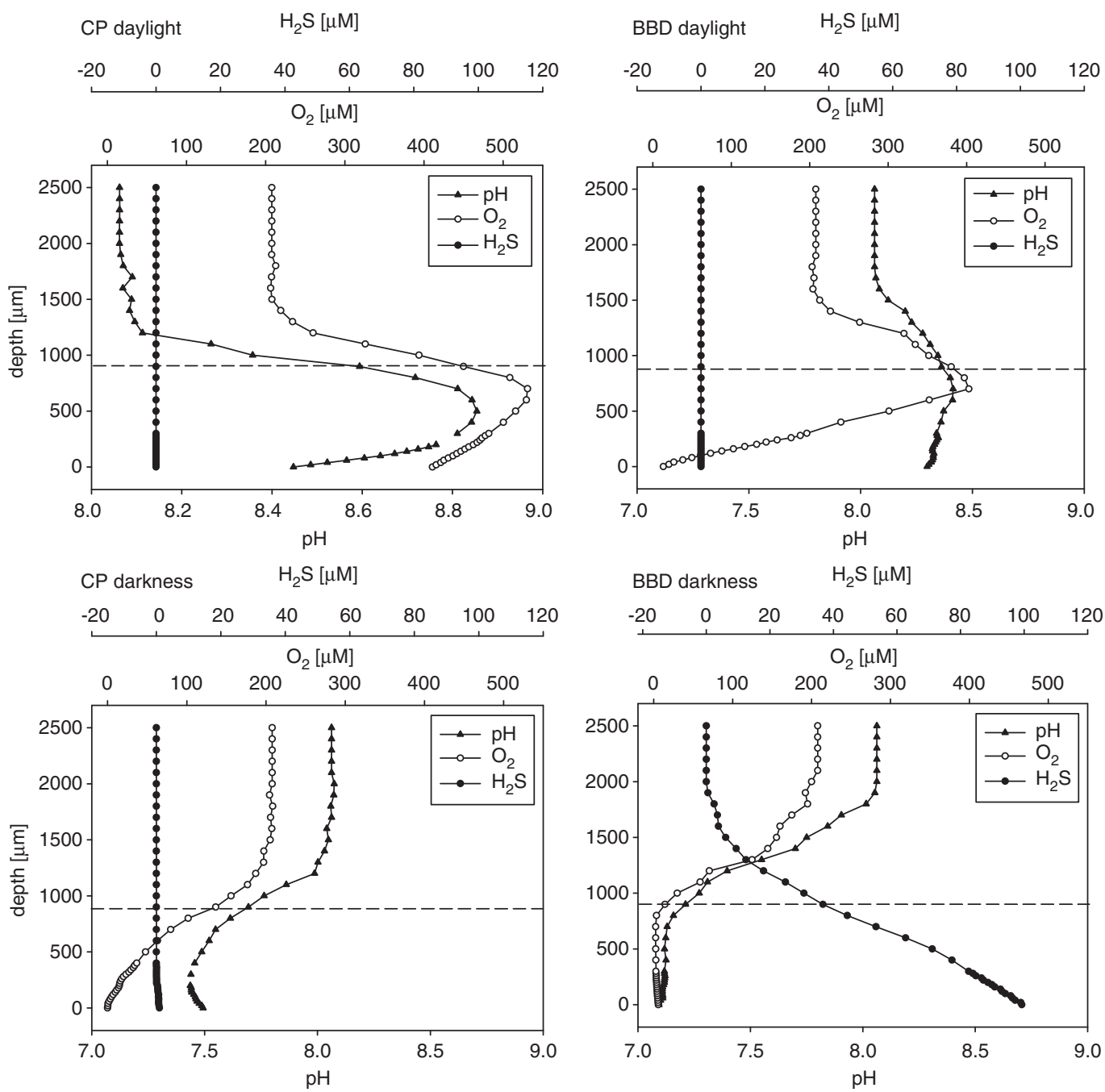

Figure 3 Exemplary dark and light profiles of $\mathrm{H}_{2} \mathrm{~S}$ and $\mathrm{pH}$ (measured at $250 \mu$ mol photons m ${ }^{-2} \mathrm{~s}^{-1}$ ) as well as $\mathrm{O}_{2}(\mathrm{measured}$ at $125 \mu \mathrm{mol}$ photons $\mathrm{m}^{-2} \mathrm{~s}^{-1}$ ) at the front of a CP and BBD microbial lesion. The dotted lines indicate the surface of the mats, which were $\sim 900 \mu \mathrm{m}$ thick.

in response to varying light levels. These microchemical environments are shaped by the microbial community within the mat, maintaining anoxia, high levels of sulphide and low $\mathrm{pH}$, especially at the coral-microbial mat interphase. Anoxia has been shown to have adverse effects on the photophysiology of endosymbiotic algae (Ulstrup et al., 2005) and overall fitness of the coral host (Shick,
1990). Furthermore, lethal concentrations of sulphide (LC50) on invertebrates (Caldwell, 1975; Bagarinao, 1992; Knezovich et al., 1996; Wang and Chapman, 1999) and coral tissue (Downs et al., 2010) have been reported as low as $0.5 \mu \mathrm{M}$ for $4 \mathrm{~h}$ of exposure, a factor $10^{4}$ lower than the maximum $S_{\text {tot }}$ concentrations measured at the base of BBD in this study. This confirms that the measured levels of $S_{\text {tot }}$ 
Table 3 Mean migration speed, $S_{\text {tot }}, \mathrm{O}_{2}$ and $\mathrm{pH}$ measured at the front and base of CP and BBD mats, along with relative quantity of sulphate-reducing bacteria, developmental stages and Chl $a$ contents of individual coral lesions. Results of linear regression analyses are given with respect to migration speed

\begin{tabular}{|c|c|c|c|c|c|c|c|}
\hline & $\begin{array}{l}\text { Migration speed }{ }^{a} \\
\text { (mm per day) }\end{array}$ & $\begin{array}{c}\text { Mean } \\
S_{\text {tot }} \text { b }(\mu M)\end{array}$ & $\begin{array}{c}\text { Mean } O_{2}{ }^{\mathrm{b}} \\
(\mu \mathrm{M})\end{array}$ & Mean $p H^{b}$ & $\begin{array}{c}\text { DSR (\% per } \\
10^{6} 16 S \text { rRNA) }\end{array}$ & $\begin{array}{c}\text { Developmental } \\
\text { stage }^{\mathrm{c}}\end{array}$ & $\begin{array}{c}\text { Chl } a^{\mathrm{d}} \\
\left(\text { Chl } \mathrm{ag}^{-1}\right)\end{array}$ \\
\hline CP no. 1 & $1.18 \pm 0.00$ & 20 & 193 & 8.53 & 2.2 & 5 & 80 \\
\hline CP no. 2 & $0.04 \pm 0.01$ & 0 & 264 & 7.77 & $<0.01$ & 2 & 212 \\
\hline CP no. 3 & $0.01 \pm 0.01$ & 0 & 278 & 8.23 & 0.5 & 2 & 313 \\
\hline BBD no. 1 & $8.63 \pm 0.03$ & 2654 & 0 & 7.83 & 9.2 & 10 & 733 \\
\hline BBD no. 2 & $4.19 \pm 0.02$ & 246 & 10 & 7.22 & 2.3 & 9 & 413 \\
\hline BBD no. 3 & $1.41 \pm 0.02$ & 46 & 113 & 7.47 & 7.8 & 8 & 267 \\
\hline \multicolumn{8}{|c|}{ Linear regression analyses $\mathrm{e}$} \\
\hline Intercept & & 1.141 & 5.976 & 18.99 & 0.3354 & -2.120 & -1.922 \\
\hline Slope & & 0.003 & -0.024 & -2.093 & 0.611 & 0.783 & 0.013 \\
\hline$R^{2}$ & & 0.856 & 0.756 & 0.091 & 0.505 & 0.684 & 0.803 \\
\hline$P$-value & & $0.008^{*}$ & $0.024 *$ & 0.561 & 0.113 & $0.042^{*}$ & $0.016^{*}$ \\
\hline
\end{tabular}

Abbreviations: BBD, black band disease; CP, cyanobacterial patch; Chl $a$, chlorophyll $a$.

${ }^{\text {a } M e a n ~ m i g r a t i o n ~ s p e e d ~ p e r ~ d a y ~}(n=5, \pm$ s.e.).

${ }^{\mathrm{b}}$ Mean over light $\left(S_{\text {tot }}\right.$, $\mathrm{pH} 250$ and $\mathrm{O}_{2} 125 \mu \mathrm{mol}$ photons $\left.\mathrm{m}^{-2} \mathrm{~s}^{-1}\right)$ and dark conditions.

${ }^{\mathrm{c}}$ Developmental stage of lesions assessed by visual inspection.

dStated per wet weight of mats.

eSignificance levels at the $5 \%$ level are indicated by *

and anoxia in BBD lesions can easily kill coral tissue on short time scales of 1-2 days, during which the microbial mat covers and progresses over the underlying coral tissue. The effects of anoxia and high levels of $S_{\text {tot }}$ in BBD drive a high mean migration speed (i.e., virulence) of the lesions, as shown by significant positive linear correlations (Table 3). These deleterious microchemical conditions are established very fast in the dark $\left(t_{90}<10 \mathrm{~min}\right.$; owing to the mats' thinness, which facilitates diffusion), which is in accordance with the fast progression rates of BBD measured in this study ex situ (Table 3) and in situ (Richardson, 1996; Sato et al., 2009).

In contrast to BBD lesions, the CP microbial mats exhibited no clear vertical stratification into phototrophic-oxygenic and anoxic-sulphidic zones. Consequently, $\mathrm{O}_{2}$ was present throughout the mat in light (Figure 3), with only a single sample showing marginal sulphide concentrations in the dark and at intermediate irradiances (Figure 2 and Supplementary Figure S1). These conditions resulted in slower mean migration rates and hence lowered virulence of CP compared with BBD measured ex situ (Table 3) and in situ (Sato et al., 2010).

As both hypoxia and Chl a contents increased with increasing migration speed of all lesions (Table 3), stratification of lesions into photosynthetic and anoxic-sulphidic zones became more pronounced as the lesions developed and virulence increased. This suggests that high cyanobacterial biomass facilitates the biogeochemical stratification as the lesions develop. The results thus show that stratification of the mat community into a phototrophic and anaerobic sulphate reduction zone is essential for the development of anoxia, low $\mathrm{pH}$, high sulphide levels (in darkness) and therefore the increased virulence of BBD compared with CP.
Sulphate reduction and desulphuration in $B B D$ and $C P$ Both bacterial sulphate reduction and desulphuration of degrading coral tissue and mucus (Hill et al., 1995; Brown and Bythell, 2005) are potential sources of sulphide production at the coral-BBD microbial mat interphase. SRB typically proliferate under anoxic, sulphate-rich conditions made available by degrading tissue of BBD-infected corals. This is consistent with the strongly increased presence of SRB within BBD, representing between $\sim 2-9 \%$ of the bacterial population within the lesions compared with CP (Table 3). In addition to sulphide production by SRB, coral tissue and mucus desulphuration by microbes and remaining coral-derived enzymes is the most likely source of sulphide emergence (Weber, 2009). As sulphate-reduction rates were not measured in this study, distinguishing between the two sources is not feasible. Nevertheless, the BBD mat covering degrading coral tissue will strongly facilitate desulphuration and sulphate reduction and thereby considerably enhance virulence of BBD lesions compared with non-covered degrading coral tissue.

\section{Proposed positive feedback mechanism causing} $B B D$ virulence

The stratification of BBD lesions indicates an interaction between the sulphide-tolerant phototrophic cyanobacteria (Myers and Richardson, 2009), SRB and desulphuration. Positive phototaxis in daylight and production of sulphide in darkness (negative chemotaxis) will drive motile cyanobacteria into the upper layer of BBD lesion, thereby creating a positive feedback loop for anoxic conditions at its base. Increased anoxia at the base will facilitate sulphate reduction by SRB and desulphuration and lower sulphide oxidation, which in 
turn will drive negative cyanobacterial chemotaxis against increasing sulphide levels. Sulphide production, via chemical oxidation, further facilitates the presence of anoxia and indirectly lower $\mathrm{pH}$, which again will increase disease virulence at the base of the mat. The three synergistic lethal factors (i.e., anoxia, high concentrations of $S_{\text {tot }}$ and low $\mathrm{pH}$ ) thus reciprocally enhance one another at the coralBBD microbial mat interphase through the feedback mechanisms described above and can thereby easily create a positive feedback loop for disease virulence.

The strong horizontal and vertical gradients of sulphide in the BBD mats are in agreement with the availability of sulphate, which is limited by the presence of necrosed coral tissue at the progression front of the mat, hence its migration direction (Figure 1). The necrosed coral tissue can easily be decomposed through microbial activity (readily available within the mat of $\mathrm{BBD}$ ) and remaining coral-derived cellular enzymes, resulting in the presence of high concentrations of sulphate. Anaerobic sulphate reduction is therefore proposed to be biogeochemically facilitated at the coral-microbial mat interphase. Desulphuration and the availability of sulphate for SRB are therefore expected to decrease along the migration gradient of the BBD mat, as suggested by the consistently observed equivalent sulphide microgradients (Figure 2). The stronger correlation of migration rates in $\mathrm{CP}$ and BBD with $S_{\text {tot }}$, anoxia and Chl $a$ contents, rather than relative abundances of $d s r A$ copy numbers (Table 3 ), indicates that the accumulation of $S_{\text {tot }}$ by anaerobic sulphate reduction and desulphuration, rather than the presence or abundance of identified pathogenic microbial members, determines the virulence of these diseases.

The findings of this study indicate that the BBD microbial consortium as a whole establishes biogeochemical conditions at the coral-microbial mat interphase that are lethal for coral tissue. By comparing CP with BBD lesions it was shown that stratification of mats into an upper phototrophic and lower anoxic-sulphidic zone is essential for establishing such high disease virulence. The presented findings therefore indicate that steep biogeochemical microgradients, produced and maintained by the entire microbial consortium of BBD, are the major cause for the high virulence of this disease.

\section{Acknowledgements}

We especially want to thank Peter Stief, Mohammad Al-Najjar and Lubos Polerecky for fruitful and constructive comments during the data analysis. Dirk de Beer is thanked for constructive comments on the manuscript. We are very grateful to Vera Hübner, Ines Schröder, Cecilia Wigand and Anja Niclas for help with preparations of the microsensors. We also want to thank Andrew Muirhead and Jason Doyle for technical help. This research was funded by the Australian Institute of Marine Science and the Max Planck Institute for Marine Microbiology.

\section{References}

Antonius A. (1973). New observations on coral destruction in reefs. In: 10th Meeting of the Association of Island Marine Laboratories of the Caribbean, University of Puerto Rico: Association of Island Marine Laboratories of the Caribbean: Mayaguez, Puerto Rico, p 3.

Bagarinao T. (1992). Sulfide as an environmental factor and toxicant: tolerance and adaptations in aquatic organisms. Aquat Toxicol 24: 21-62.

Barneah O, Ben-Dov E, Kramarsky-Winter E, Kushmaro A. (2007). Characterization of black band disease in Red Sea stony corals. Environ Microbiol 9: 1995-2006.

Bourne DG, Muirhead A, Sato Y. (2011). Changes in sulfate-reducing bacterial populations during the onset of black band disease. ISME J 5: 559-564.

Brown BE, Bythell JC. (2005). Perspectives on mucus secretion in reef corals. Mar Ecol Progr Ser 296: 291-309.

Caldwell R. (1975). Hydrogen Sulfide Effects on Selected Larval and Adult Marine Invertebrates. Water Resource Research Institute, Oregon State University: Corvallis.

Carlton RG, Richardson LL. (1995). Oxygen and sulfide dynamics in a horizontally migrating cyanobaterial mat: Black band disease of corals. FEMS Microbiol Ecol 18: 155-162.

Cooney RP, Pantos O, Le Tissier MDA, Barer MR, O’Donnell AG, Bythell JC. (2002). Characterization of the bacterial consortium associated with black band disease in coral using molecular microbiological techniques. Environ Microbiol 4: 401-413.

De Beer D. (2000). Potentiometric microsensors for in situ measurements in aquatic environments. In: Buffle J, Horvai G (eds). In Situ Monitoring of Aquatic Systems: Chemical Analysis and Speciation. Wiley \& Sons: London, pp 161-194.

Dillon JG, Miller S, Bebout B, Hullar M, Pinel N, Stahl DA. (2009). Spatial and temporal variability in a stratified hypersaline microbial mat community. FEMS Microbiol Ecol 68: 46-58.

Downs CA, Fauth JE, Downs VD, Ostrander GK. (2010). In vitro cell-toxicity screening as an alternative animal model for coral toxicology: effects of heat stress, sulfide, rotenone, cyanide, and cuprous oxide on cell viability and mitochondrial function. Ecotoxicology 19: 171-184.

Dupraz C, Reid RP, Braissant O, Decho AW, Norman RS, Visscher PT. (2009). Processes of carbonate precipitation in modern microbial mats. Earth-Sci Rev 96: 141-162.

Dupraz C, Visscher PT, Baumgartner LK, Reid RP. (2004). Microbe-mineral interactions: early carbonate precipitation in a hypersaline lake (Eleuthera Island, Bahamas). Sedimentology 51: 745-765.

Fourcans A, Sole A, Diestra E, Ranchou-Peyruse A, Esteve $\mathrm{I}$, Caumette $\mathrm{P}$ et al. (2006). Vertical migration of phototrophic bacterial populations in a hypersaline microbial mat from Salins-de-Giraud (Camargue, France). FEMS Microbiol Ecol 57: 367-377.

Frias-Lopez J, Klaus JS, Bonheyo GT, Fouke BW. (2004). Bacterial community associated with black band disease in corals. Appl Environ Microbiol 70: 5955-5962.

Glas MS, Motti CA, Negri AP, Sato Y, Froscio S, Humpage AR et al. (2010). Cyanotoxins are not implicated in the etiology of coral black band disease outbreaks on Pelorus Island, Great Barrier Reef. FEMS Microbiol Ecol 73: 43-54. 
Hill RW, Dacey JWH, Krupp DA. (1995). Dimethylsulfoniopropionate in reef corals. Bull Mar Sci 57: 489-494.

Hinck S, Neu TR, Lavik G, Mussmann M, De Beer D, Jonkers HM. (2007). Physiological adaptation of a nitrate-storing beggiatoa $\mathrm{sp}$ to diel cycling in a phototrophic hypersaline mat. Appl Environ Microbiol 73: 7013-7022.

Jeroschewski P, Steukart C, Kühl M. (1996). An amperiometric microsensor for the determination of $\mathrm{H}_{2} \mathrm{~S}$ in aquatic environments. Anal Chem 68: 4351-4357.

Jonkers HM, Ludwig R, De Wit R, Pringault O, Muyzer G, Niemann $\mathrm{H}$ et al. (2003). Structural and functional analysis of a microbial mat ecosystem from a unique permanent hypersaline inland lake: 'La Salada de Chiprana' (NE Spain). FEMS Microbiol Ecol 44: 175-189.

Knezovich JP, Steichen DJ, Jelinski JA, Anderson SL. (1996). Sulfide tolerance of four marine species used to evaluate sediment and pore-water toxicity. Bull Environ Contam Toxicol 57: 450-457.

Kondo R, Shigematsu K, Butani J. (2008). Rapid enumeration of sulphate-reducing bacteria from aquatic environments using real-time PCR. Plankton Benthos Res 3: 180-183.

Kühl M, Steuchart C, Eickert G, Jeroschewski P. (1998). A $\mathrm{H}_{2} \mathrm{~S}$ microsensor for profiling biofilms and sediments: application in an acidic lake sediment. Aquat Microb Ecol 15: 201-209.

Leloup J, Loy A, Knab NJ, Borowski C, Wagner M, Jorgensen BB. (2007). Diversity and abundance of sulfate-reducing microorganisms in the sulfate and methane zones of a marine sediment, Black Sea. Environ Microbiol 9: 131-142.

Ludwig R, Al-Horani FA, de Beer D, Jonkers HM. (2005). Photosynthesis-controlled calcification in a hypersaline microbial mat. Limnol Oceanogr 50: 1836-1843.

Millero FJ, Hershey JP. (1989). Thermodynamics and kinetics of hydrogen sulfide in natural waters. Mar Chem 18: 121-147.

Millero FJ, Plese T, Fernandez M. (1988). The dissociation of hydrogen sulfide in seawater. Limnol Oceanogr 33: 269-274.

Myers JL, Richardson LL. (2009). Adaptation of cyanobacteria to the sulfide-rich microenvironment of black band disease of coral. FEMS Microbiol Ecol 67: 242-251.

Nadkarni MA, Martin FE, Jacques NA, Hunter N. (2002). Determination of bacterial load by real-time PCR using a broad-range (universal) probe and primers set. Microbiology 148: 257-266.

Polerecky L, Bachar A, Schoon R, Grinstein M, Jorgensen $\mathrm{BB}$, de Beer D et al. (2007). Contribution of Chloroflexus respiration to oxygen cycling in a hypersaline microbial mat from Lake Chiprana, Spain. Environ Microbiol 9: 2007-2024.

Porra RJ. (2002). The chequered history of the development and use of simultaneous equations for the accurate determination of chlorophylls a and b. Photosynthesis Res 73: 149-156.

Revsbech NP, Jørgensen BB. (1986). Microelectrodes: their use in microbial ecology. Adv Microb Ecol 9: 293-352.

Richardson LL. (1996). Horizontal and vertical migration patterns of Phormidium corallyticum and Beggiatoa spp associated with black-band disease of corals. Microb Ecol 32: 323-335.

Richardson LL. (2004). Black band disease. In: Rosenberg E, Loya Y (eds). Coral Health and Disease. Springer Berlin: Berlin, Heidelberg, New York, pp 325-349.

Richardson LL, Kuta KG, Schnell S, Carlton RG. (1997). Ecology of the black band disease microbial consortium. Proceedings of the 8th International Coral Reef Symposium, Vol. 1. Panama City, Panama, pp 597-600.

Sato Y, Bourne DG, Willis BL. (2009). Dynamics of seasonal outbreaks of black band disease in an assemblage of Montipora species at Pelorus Island (Great Barrier Reef, Australia). Proc R Soc B Biol Sci 276: 2795-2803.

Sato Y, Willis BL, Bourne DG. (2010). Successional changes in bacterial communities during the development of black band disease on the reef coral, Montipora hispida. ISME J 4: 203-214.

Sekar R, Kaczmarsky LT, Richardson LL. (2008). Microbial community composition of black band disease on the coral host Siderastrea siderea from three regions of the wider Caribbean. Mar Ecol Progr Ser 362: 85-98.

Shick JM. (1990). Diffusion limitation and hyperoxic enhancement of oxygen-consumption in zooxanthellate sea-anemones, zoanthids, and corals. Biol Bull 179: 148-158.

Sutherland KP, Porter JW, Torres C. (2004). Disease and immunity in Caribbean and Indo-Pacific zooxanthellate corals. Mar Ecol Progr Ser 266: 273-302.

Ulstrup KE, Hill R, Ralph PJ. (2005). Photosynthetic impact of hypoxia on in hospite zooxanthellae in the scleractinian coral Pocillopora damicornis. Mar Ecol Progr Ser 286: 125-132.

Vismann B. (1991). Sulfide tolerance - physiological-mechanisms and ecological implications. Ophelia 34: 1-27.

Voss JD, Mills DK, Myers JL, Remily ER, Richardson LL. (2007). Black band disease microbial community variation on corals in three regions of the wider Caribbean. Microb Ecol 54: 730-739.

Wang F, Chapman PM. (1999). Biological implications of sulfide in sediment-a review focusing on sediment toxicity. Environ Toxicol Chem 18: 2526-2532.

Weber M. (2009). How sediment damages corals. PhD thesis, University of Bremen, Bremen.

Supplementary Information accompanies the paper on The ISME Journal website (http://www.nature.com/ismej) 